\title{
Optimization of culture conditions for callus proliferation of Curculigo orchioides Gaertn.
}

\author{
T. T. T. Nguyen ${ }^{1,2}$, D. T. P. Nhung ${ }^{1,3}$, N. T. N. Man ${ }^{1,4}$, T. T. N. ${ }^{1,5}$, N. H. An ${ }^{1,6}$, T. T. B. Phuong ${ }^{1,7 *}$ \\ ${ }^{1}$ Department of Biology, Hue University of Sciences, Hue University, Nguyen Hue St., 77, Thua Thien Hue, 49000, Vietnam \\ 2E-mail: tttnguyen6597@gmail.com; ORCID iD: https://orcid.org/0000-0003-1273-934X \\ ${ }^{3}$ E-mail: doanphuongnhung.stvt@gmail.com; ORCID iD: https://orcid.org/0000-0003-0258-1227 \\ ${ }^{4}$ E-mail: dinhhuongtu999@gmail.com; ORCID iD: https://orcid.org/0000-0001-7849-5136 \\ ${ }^{5}$ E-mail: trannhuy980@gmail.com; ORCID iD: https://orcid.org/0000-0003-1837-7626 \\ ${ }^{6}$ E-mail: billyleopard97@gmail.com; ORCID iD: https://orcid.org/0000-0001-6270-0764 \\ ${ }^{7}$ E-mail: ttbphuong@hueuni.edu.vn, ttbphuongdt@gmail.com; ORCID iD: https://orcid.org/0000-0002-8049-8499 \\ *Corresponding author
}

Keywords: inhibitors, kinetin, mineral medium, $\alpha$-naphthaleneacetic acid (NAA), photoperiod.

Summary. Curculigo orchioides Gaertn is a herbaceous plant that has long been used as a tonic in Vietnam with noticeable health benefits. However, the demand for rhizomes of this species could not be met due to their decreasing number in natural habitats. Despite its vulnerability, there are still not enough researches on producing calli of C. orchioides, which is a method having the capacity of creating a large source of cell biomass for bioactive compounds' extractions. Thus, this study was conducted to figure out the best conditions for $C$. orchioides's callus proliferation. Different light regimes, mineral media, and concentrations of some factors like kinetin (KIN), $\alpha$-naphthaleneacetic acid (NAA), yeast extract (YE), activated charcoal (AC), and silver nitrate $\left(\mathrm{AgNO}_{3}\right)$ were examined. It is shown by the results that half-strength MS medium ( $(1 / 2 \mathrm{MS})$ given $0.5 \mathrm{mg} / \mathrm{L} \mathrm{KIN} \mathrm{and} \mathrm{MS} \mathrm{medium} \mathrm{supplemented} \mathrm{with} 0.5 \mathrm{mg} / \mathrm{L}$ KIN and put in the dark (0 light hour : 24 dark hours) are the optimal conditions for callus proliferation, with the highest fresh weights $(F W \mathrm{~s})$, dry weights $(D W \mathrm{~s})$, and growth indices $(G I \mathrm{~s})$ of $3.89 \mathrm{~g} / 0.45 \mathrm{~g} / 7.78$, and $4.10 \mathrm{~g} / 0.47$ $\mathrm{g} / 8.20$, respectively. Additionally, the inhibitory effects of $\mathrm{AgNO}_{3}, \mathrm{YE}$, and $\mathrm{AC}$ were demonstrated since there was no observed heavy callus in the media containing those factors.

\section{Оптимизация условий культивирования для пролиферации каллусов Curculigo orchioides Gaertn.}

\author{
Т. Т. Т. Нгуен, Д. Т. П. Нхунг, Н. Т. Н. Ман, Т. Т. Н. Й, Н. Х. Ан, Т. Т. Б. Фуонг \\ Департамент биологии, Университет Хюэ, ул. Нгуен Хюэ, 77, Тхуа Тхиен Хюэ, 49000, Вьетнам
}

Ключевые слова: ингибиторы, кинетин, минеральная среда, фотопериод, $\alpha$-нафталинуксусная кислота.

Aннотация. Curculigo orchioides Gaertn - это травянистое растение, которое долгое время использовалось во Вьетнаме как тонизирующее средство. Однако потребность в корневищах этого вида не может быть полностью удовлетворена из-за уменьшения их численности в естественных местообитаниях. Несмотря на уязвимость вида, до сих пор недостаточно исследований по производству каллусов C. orchioides для экстракции биологически активных соединений. Таким образом, это исследование направлено на улучшение условий для разрастания каллуса $C$. orchioides. Были исследованы различные режимы освещения, минеральные среды 
и концентрации в них таких веществ, как кинетин (KIN), $\alpha$-нафталинуксусная кислота (NAA), дрожжевой экстракт (YE), активированный уголь (AC) и нитрат серебра $\left(\mathrm{AgNO}_{3}\right)$. Результаты показывают, что среда MS половинной концентрации ( $1 / 2 \mathrm{MS})$ при 0,5 мг/л KIN и среда MS с добавлением 0,5 мг/л KIN, в условиях темноты (0 световых часов: 24 темных часа) является оптимальной для размножения каллуса с наивысшими значениями сырого веса $(F W s)$, сухого веса $(D W s)$ и индексов роста $(G I \mathrm{~s}): 3,89$ г / 0,45 г / 7,78 и 4,10 г / 0,47 г / 8,20 , соответственно. Кроме того, продемонстрированы ингибирующие эффекты $\mathrm{AgNO}_{3}$, YЕ и АC, поскольку в среде, содержащей эти факторы, не наблюдалось увеличения каллуса.

\section{Introduction}

Curculigo orchioides Gaertn. (Hypoxidaceae) is a medicinal plant growing in tropical monsoon regions. The rhizome of this species contains many metabolites (flavone, glycoside, steroid, saponin, and triterpenoid) with remarkable health benefits including antidiabetic, preventing bone loss, antiasthmatic, hepatoprotective, antimicrobial, and antifungal effects (Kubo, 1983; Jaiswal, 1984; Misra, 1984; Misra, 1990; Xu J. P., Xu R. S., 1992; Venukumar, Latha, 2002; Lakshmi, 2004; Chauhan, Dixit, 2007; Madhavan, 2007; Cao, 2008; Pandit, 2008; Nagesh, Shanthamma, 2009; Singh, 2009; Agrahari, 2010; Zou, 2010). Unfortunately, the number of $C$. orchioides individuals is falling rapidly due to deforestation and over-exploiting of rhizomes for medicine production (Wala, Jasrai, 2003). The extensive utilization of $C$. orchioides rhizomes was caused by the inefficient bioactive compound extraction based on whole plants since secondary metabolites' abundance in plant individuals is low (less than $1 \%$ of the total carbon) (Bourgaud, 2001). Thus, it is crucial to find a method for meeting the urgent demand of $C$. orchioides's secondary compounds without decreasing their number.

Callus induction is the most suitable procedure for satisfying the mentioned need since it can greatly increase cell biomass to produce large amounts of secondary metabolites without depending on the traditionally cultivated plants (Ahn, 1996). Though callus cells are genetically unstable, this problem can be solved by continuously subculturing calli for a long period (from several weeks to several years) until their growth parameters remain unchanged after three consecutive subculture cycles to create stable cell lines (Fett Neto, 1994; Miura, 1998; Bourgaud, 2001; Miguel-Chavez, 2007; Jin, Keng, 2013; Biswas, 2013). However, there are few published studies on callus induction of C. orchioides. In particular, Nagesh et al. (2010) indicated that the highest callus formation level was obtained in the medium supplemented with $0.5 \mathrm{mg} / \mathrm{L}$ BAP (6-benzylaminopurine) and $3 \mathrm{mg} / \mathrm{L}$ 2,4-D (2,4-dichlorophenoxyacetic acid). Moreover, as it was proven in Dhenuka et al.'s study (1999), proliferating green callus was given rise from leaf explants by using MS (Murashige, Skoog, 1962) medium added with $9 \mu \mathrm{M}$ BAP.

Because of $C$. orchioides's low number in their natural habitats and the lack of studies on callus proliferation of this valuable plant, we investigated the impacts of different factors on callus growth of C. orchioides to create a sufficient source of biomass for extracting bioactive compounds. Several factors (mineral media, photoperiods, yeast extract (YE), activated charcoal (AC), and silver nitrate) were tested for the first time to find new stimuli and inhibitors of $C$. orchioides 's callus formation, which could then be applied in the cell culture stage of secondary metabolites' productions.

\section{Materials and methods}

\section{Plant materials}

Primary calli provided by the Department of Biology, University of Sciences (Thua Thien Hue, Vietnam) were utilized as materials in this study.

\section{Effects of several factors on callus proliferation}

To optimize the condition for callus growth, the following experiments were conducted; each experiment lasted for four weeks:

1. Different concentrations of kinetin (KIN) $(0,0.5,1.0,1.5,2.0,2.5$, and $3.0 \mathrm{mg} / \mathrm{L})$ were supplemented into the MS medium to determine the best KIN amount, which was then used in further experiments.

2. Combinations between the most suitable KIN concentration and different NAA $(\alpha$-naphthaleneacetic acid) amounts $(0,0.5,1.0,1.5$, 2.0 , and $2.5 \mathrm{mg} / \mathrm{L}$ ) were also tested to find out the optimal NAA concentration.

3. Basal MS medium, half-strength MS medium (1/2 MS), and quarter-strength MS medium (1/4 MS) were compared to point out the most suitable mineral medium.

4. The proper photoperiod was figured out by comparing two conditions namely 0 hour and 16 hours of light per day. 
5. To examine the effect of silver nitrate $\left(\mathrm{AgNO}_{3}\right)$ on callus proliferation, $0,0.5,1.0$, and $1.5 \mathrm{mg} / \mathrm{L}$ $\mathrm{AgNO}_{3}$ were added into the MS medium.

6. The impact of YE on multiplying $C$. orchioides callus was investigated by supplementing different quantities of YE $(0,100,200,300$, and $400 \mathrm{mg} / \mathrm{L})$ into the MS medium.

7. To indicate how calli grow in medium with $\mathrm{AC}$, $0,0.5,1.0$, and $1.5 \mathrm{~g} / \mathrm{L}$ of $\mathrm{AC}$ were supplemented into the MS medium.

The conclusion of the optimal condition for callus multiplication was made by statistically comparing the best concentrations of the above factors.

\section{Culture conditions}

In each experiment, $0.5 \mathrm{~g}$ callus was cultured on different media, containing $30 \mathrm{~g} / \mathrm{L}$ sucrose and $8 \mathrm{~g} / \mathrm{L}$ agar.

All media $(\mathrm{pH}=5.8-6.0)$ were autoclaved at $121{ }^{\circ} \mathrm{C}, 1 \mathrm{~atm}$ for 20 minutes, after which $20 \mathrm{~mL}$ was poured into $100 \mathrm{~mL}$ glass bottles covered by 2 layers of aluminum foils.

Cultures were incubated at the temperature of 24-26 ${ }^{\circ} \mathrm{C}$, under white LED tubes $(1.2 \mathrm{~m})$, with each tube's photon flux density of $34 \mu \mathrm{mol} / \mathrm{m}^{2} \mathrm{~s}$.

\section{Data analysis}

The growth index (GI) of callus after four weeks of culturing was calculated as following:

$$
G I=\frac{F W}{I W}
$$

Where $F W$ is the average callus fresh weight after four weeks, $I W$ is the initial weight of the primary callus.

All experiments were repeated three times so that the sample size for each treatment was 30 bottles (10 bottles per replicate).

Means were compared by Duncan's test (Duncan, 1955) $(\alpha=0.05)$ using SPSS software (version 20). Bar charts were drawn using Microsoft Excel (2013).

\section{Results}

Effects of plant growth regulators (PGRs) on callus proliferation

As it is highlighted in Table 1, low KIN concentration has a positive impact on callus growth. Specifically, $F W$, dry weight $(D W)$, and $G I$ of calli reached the peaks of $2.31,0.36$, and 4.62 respectively on MS medium given $0.5 \mathrm{mg} / \mathrm{L} \mathrm{KIN}$. Low levels of callus growth were observed in media with higher KIN concentrations $(1.0-3.0 \mathrm{mg} / \mathrm{L})$ (Fig. 1a).

Being similar to KIN, the greatest stimulatory effect of NAA was obtained at low concentration. Particularly, $0.5 \mathrm{mg} / \mathrm{L}$ is the optimal NAA amount, with maximum $F W$ and $G I$ of 3.8 and 7.6 respectively. However, many calli growing on media containing NAA are black, watery, and have the average $D W$ values being lower than the ones on medium supplemented with $0.5 \mathrm{mg} / \mathrm{L} \mathrm{KIN}$ alone (Table 2, Fig. 1b).

Table 1

Effect of KIN concentrations on callus proliferation after 4 weeks of culturing

\begin{tabular}{cccc}
\hline KIN $(\mathrm{mg} / \mathrm{L})$ & $F W(\mathrm{~g})$ & $D W(\mathrm{~g})$ & $G I$ \\
\hline 0.0 & - & - & - \\
0.5 & $\mathbf{2 . 3 1}^{\mathrm{a}}$ & $\mathbf{0 . 3 6}^{\mathrm{a}}$ & $\mathbf{4 . 6 2}$ \\
1.0 & $2.05^{\mathrm{ab}}$ & $0.24^{\mathrm{ab}}$ & 4.10 \\
1.5 & $2.04^{\mathrm{ab}}$ & $0.23^{\mathrm{ab}}$ & 4.08 \\
2.0 & $1.81^{\mathrm{ab}}$ & $0.21^{\mathrm{ab}}$ & 3.62 \\
2.5 & $1.70^{\mathrm{ab}}$ & $0.19^{\mathrm{b}}$ & 3.40 \\
3.0 & $1.65^{\mathrm{b}}$ & $0.17^{\mathrm{b}}$ & 1.30 \\
\hline
\end{tabular}

* Note (applied for Table 1-5): Within a column, means having a letter in common are not significantly different by Duncan's test $(p<0.05)$.

Effects of different mineral media on callus proliferation

Lowering compounds' quantities in MS medium stimulates the formation of large calli. However, callus proliferation is inhibited on a medium whose compounds are over-eliminated. In particular, $1 / 2$ MS is the optimal mineral medium for callus growth (with the greatest $F W, D W$, and $G I$ of $3.89,0.45$, and 7.78 respectively) while $1 / 4 \mathrm{MS}$ is the most unsuitable medium of all examined ones since no callus with high $F W, D W$ and $G I$ was observed (Table 3, Fig. 2a). Additionally, $1 / 2 \mathrm{MS}$ medium with $0.5 \mathrm{mg} / \mathrm{L}$ KIN is between the two best culture conditions for the proliferation of $C$. orchioides callus (Fig. 4). 

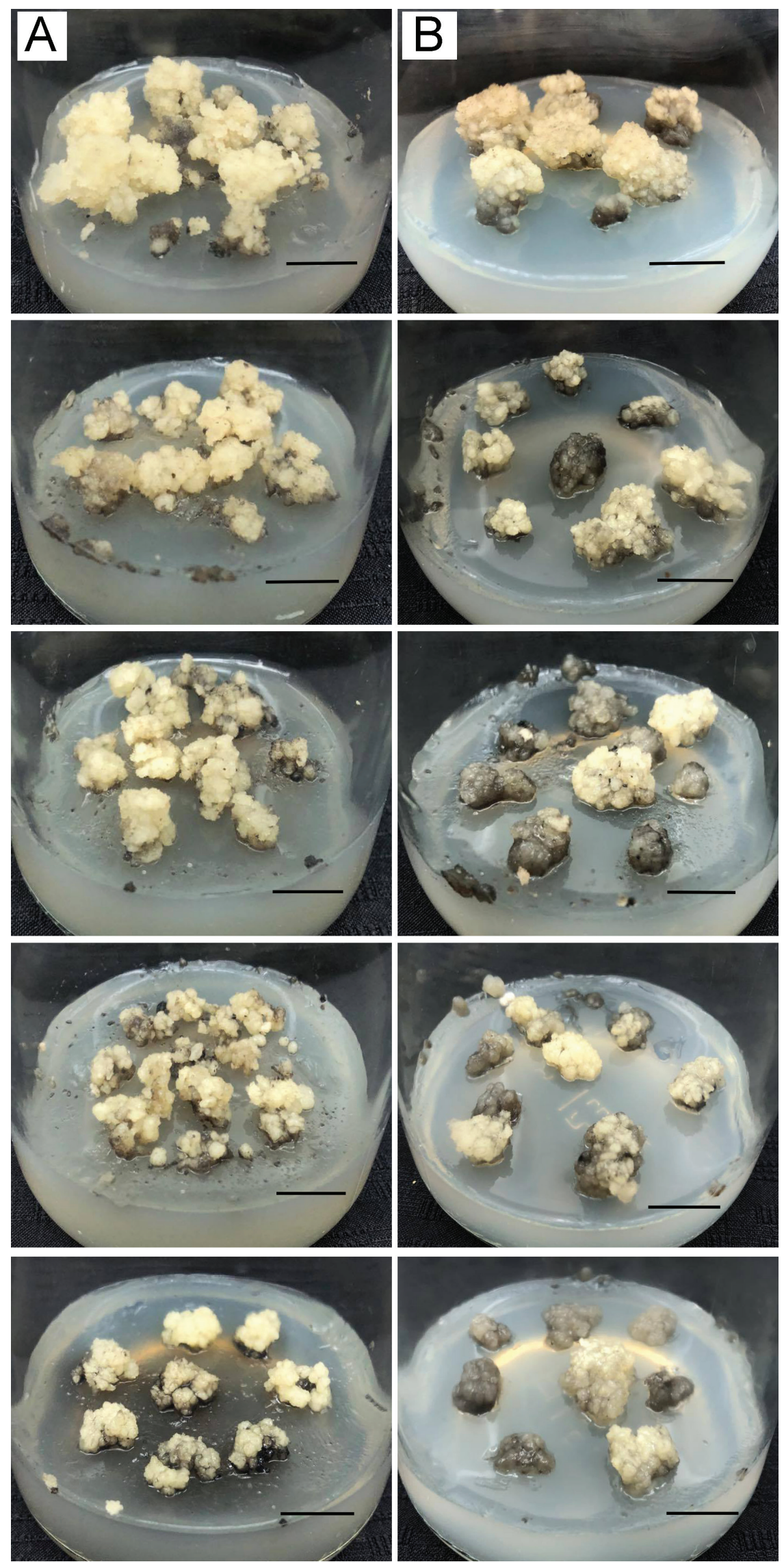

Fig. 1. The colours and morphological features of calli cultured on media with different $\mathrm{KIN}$ amounts $(0.5-2.5 \mathrm{mg} / \mathrm{L}$, from top to bottom) (A) and combinations between $0.5 \mathrm{mg} / \mathrm{L} \mathrm{KIN} \mathrm{and} \mathrm{NAA}(0.5-2.5 \mathrm{mg} / \mathrm{L}$, from top to bottom) (B). All calli are ivory (some of the calli are black). The number of black calli on media with NAA is higher than that on media with KIN alone. The calli separate from one another with no large cluster formed. Scale bar: $1 \mathrm{~cm}$. 

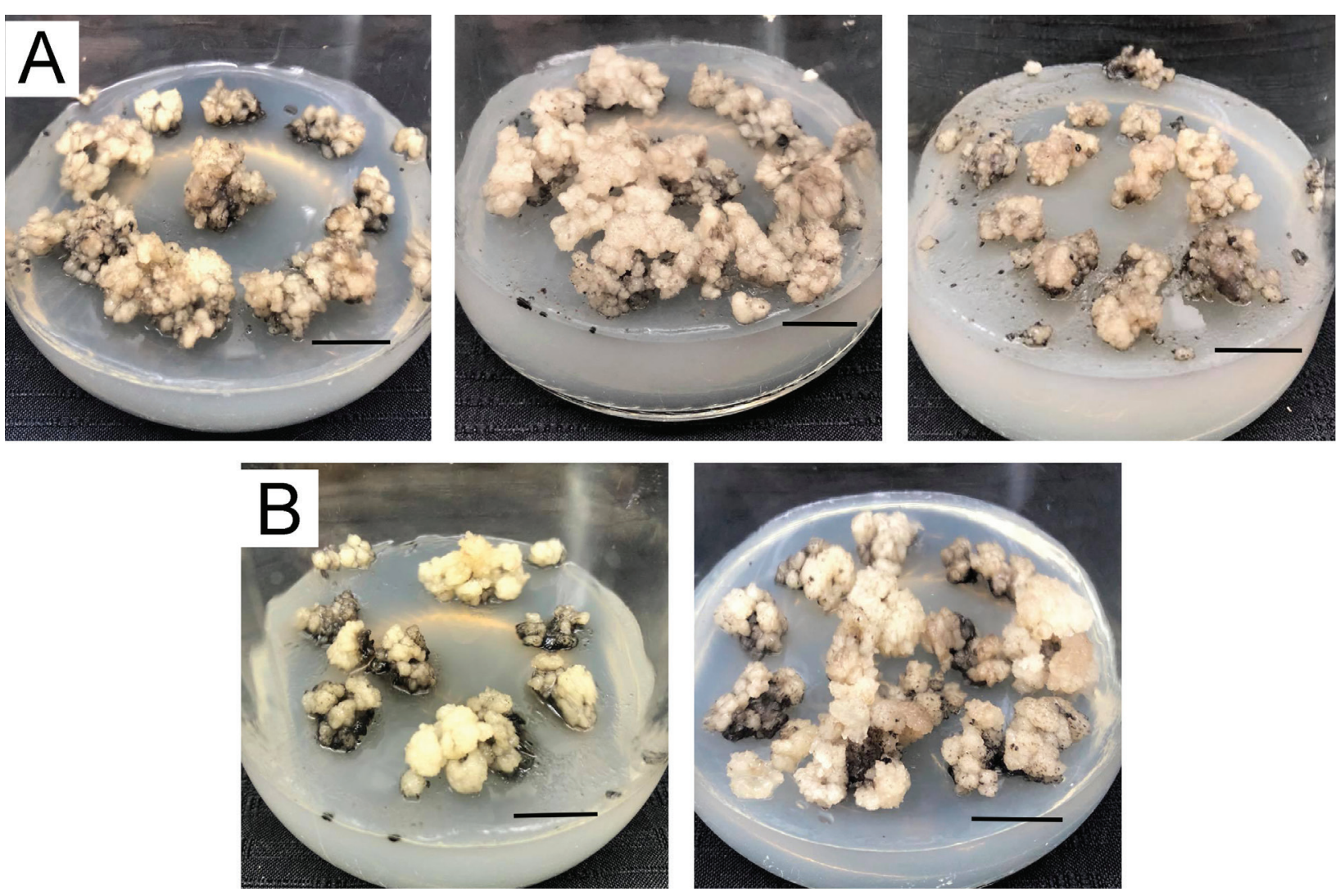

Fig. 2. Colours and morphological features of calli growing on different mineral media (MS, $1 / 2$ MS, and $1 / 4$ MS, from left to right) (A) and under different photoperiods (16 L: $8 \mathrm{D}$ and $0 \mathrm{~L}: 24 \mathrm{D}$, from left to right) (B). Almost all calli are ivory, with several ones turning black. The highest callus multiplication levels were observed on $1 / 2$ MS medium and the medium put in dark condition.

Table 2

Effects of combinations between $0.5 \mathrm{mg} / \mathrm{L} \mathrm{KIN}$ and different NAA concentrations on callus proliferation after 4 weeks of culturing

\begin{tabular}{|c|c|c|c|c|}
\hline \multicolumn{2}{|c|}{ PGRs (mg/L) } & \multirow{2}{*}{$F W(\mathrm{~g})$} & \multirow{2}{*}{$D W(\mathrm{~g})$} & \multirow{2}{*}{$G I$} \\
\hline KIN & NAA & & & \\
\hline 0.5 & 0.0 & $2.31^{\mathrm{bc}}$ & $0.36^{\mathrm{a}}$ & 4.62 \\
\hline 0.5 & 0.5 & $3.80^{\mathrm{a}}$ & $0.25^{\mathrm{ab}}$ & 7.60 \\
\hline 0.5 & 1.0 & $2.95^{\mathrm{b}}$ & $0.19^{\mathrm{ab}}$ & 5.90 \\
\hline 0.5 & 1.5 & $2.24^{\mathrm{bc}}$ & $0.15^{\mathrm{b}}$ & 4.48 \\
\hline 0.5 & 2.0 & $1.87^{\mathrm{c}}$ & $0.13^{b}$ & 3.74 \\
\hline 0.5 & 2.5 & $1.66^{\mathrm{c}}$ & $0.11^{\mathrm{b}}$ & 1.32 \\
\hline
\end{tabular}

Table 3

Effects of different mineral media on callus proliferation after 4 weeks of culturing

\begin{tabular}{ccccc}
\hline $\mathrm{KIN}(\mathrm{mg} / \mathrm{L})$ & Mineral media & $F W(\mathrm{~g})$ & $D W(\mathrm{~g})$ & $G I$ \\
\hline 0.5 & $\mathrm{MS}$ & $2.58^{\mathrm{b}}$ & $0.38^{\mathrm{b}}$ & 5.16 \\
0.5 & $1 / 2$ MS & $\mathbf{3 . 8 9}^{\mathrm{a}}$ & $\mathbf{0 . 4 5}^{\mathrm{a}}$ & $\mathbf{7 . 7 8}$ \\
0.5 & $1 / 4 \mathrm{MS}$ & $1.88^{\mathrm{c}}$ & $0.21^{\mathrm{c}}$ & 3.76 \\
\hline
\end{tabular}

Effect of photoperiod on callus proliferation

Both the light hours of 0 and 16 have positive impacts on callus growth, with high $G I$ values of 8.20 and 5.16 respectively. However, the average $F W(4.10)$ and $D W(0.47)$ of calli cultured in dark conditions are larger than those of calli growing in bottles which were illuminated 16 hours per day (Table 4, Fig. 2b). Moreover, putting calli in the dark is considered to be one of the best conditions for growth of C. orchioides callus (Fig. 4). 
Table 4

Effects of photoperiod on callus proliferation after 4 weeks of culturing

\begin{tabular}{cccc}
\hline Photoperiods (light hours : dark hours) & $F W(\mathrm{~g})$ & $D W(\mathrm{~g})$ & $G I$ \\
\hline $16: 8$ & $2.58^{\mathrm{b}}$ & $0.38^{\mathrm{b}}$ & 5.16 \\
$0: 24$ & $\mathbf{4 . 1 0}^{\mathrm{a}}$ & $\mathbf{0 . 4 7}^{\mathrm{a}}$ & $\mathbf{8 . 2 0}$ \\
\hline
\end{tabular}
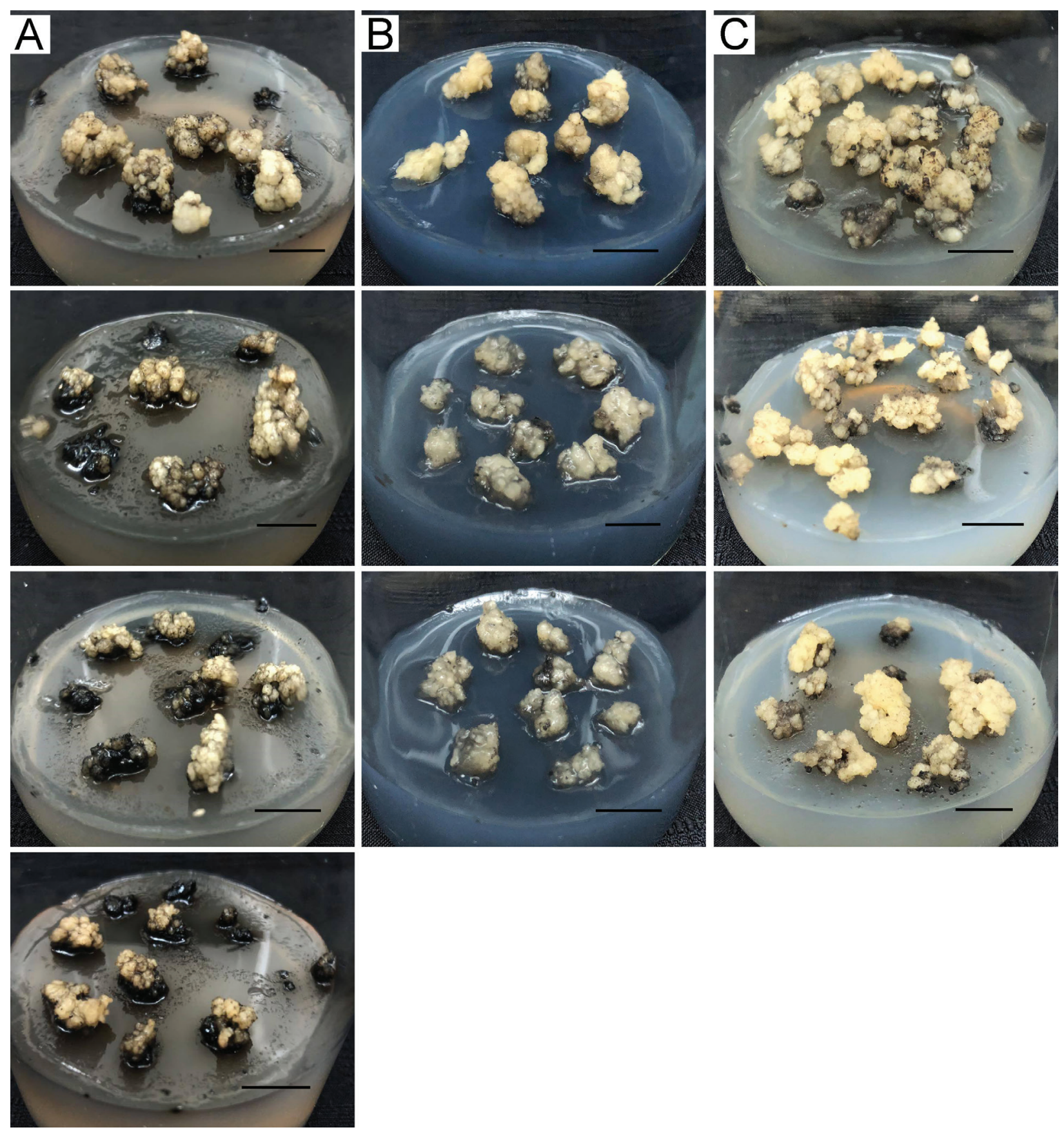

Fig. 3. The colours and morphological features of calli cultured on media with different $\mathrm{YE}(\mathrm{a}), \mathrm{AC}(\mathrm{b})$ and $\mathrm{AgNO}_{3}$ (c) concentrations, namely $0-400 \mathrm{mg} / \mathrm{L}, 0-1.5 \mathrm{~g} / \mathrm{L}$ and $0-1.5 \mathrm{mg} / \mathrm{L}$, respectively (in a figure section, factor's concentrations were ordered from top to bottom). There are inverse correlations between callus growth and the amounts of these 3 factors. Specifically, callus proliferation falls when the 3 factors' quantities increase. High numbers of black calli were observed on media with YE or AC. Additionally, no large callus cluster was found on culture media supplemented with $\mathrm{AC}, \mathrm{YE}$ or $\mathrm{AgNO}_{3}$. Scale bar: $1 \mathrm{~cm}$. 


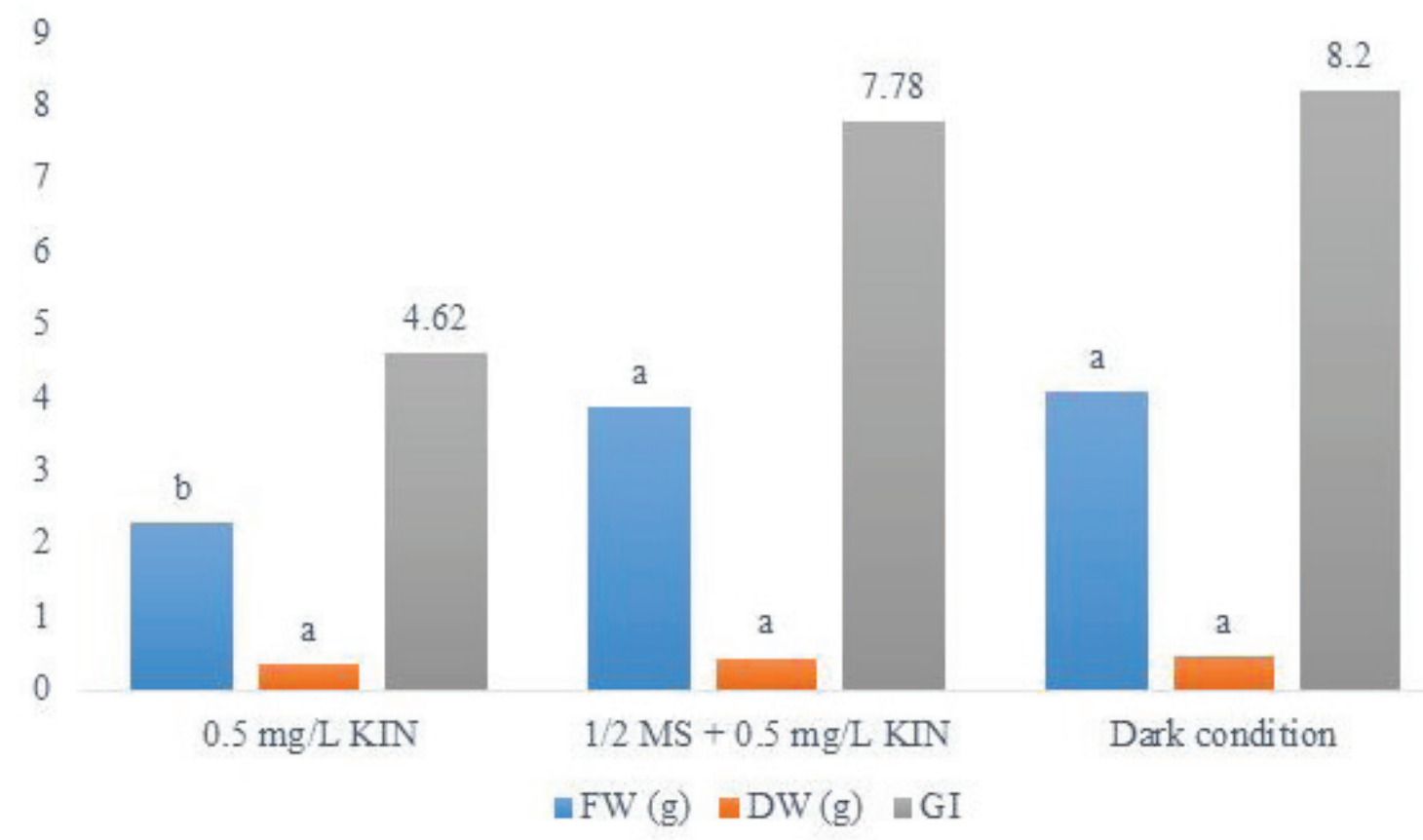

Fig. 4. Comparisons among conditions with stimulatory effects on callus proliferation, namely MS medium $+0.5 \mathrm{mg} / \mathrm{L}$ $\mathrm{KIN}, 1 / 2 \mathrm{MS}$ medium $+0.5 \mathrm{mg} / \mathrm{L} \mathrm{KIN}$ and the dark condition. Despite insignificant differences among $D W$ values of the 3 factors, $1 / 2$ MS medium supplemented with $0.5 \mathrm{mg} / \mathrm{L} \mathrm{KIN}$ and the photoperiod of $0 \mathrm{~L}: 24 \mathrm{D}$ are proven by the data to be the most suitable conditions for the growth of $C$. orchioides calli, with optimal FWs and GIs of $3.89 \mathrm{~g}-7.78$ and $4.10 \mathrm{~g}-8.2$ [Within a series, means having a letter in common are not significant different by Duncan's test $(\mathrm{p}<0.05)$ ].

Effects of YE, $\mathbf{A C}$ and $\mathbf{A g N O}_{3}$ on callus calli with high $F W, D W$, and $G I$. Additionally, calli proliferation cultured on medium with $\mathrm{AC}$ and $\mathrm{YE}$ tend to turn

It is demonstrated in Table 5 that YE, AC, black (Fig. 3). Therefore, YE, AC, and $\mathrm{AgNO}_{3}$ and $\mathrm{AgNO}_{3}$ are all inhibitors of the growth of should not be used as supplementary compounds for C. orchioides callus. Specifically, no examined callus multiplication of $C$. orchioides. concentration of these 3 factors could produce

Table 5

Effects of $\mathrm{YE}, \mathrm{AC}$ and $\mathrm{AgNO}_{3}$ on callus proliferation after 4 weeks of culturing

\begin{tabular}{ccccccc}
\hline $\mathrm{KIN}(\mathrm{mg} / \mathrm{L})$ & $\mathrm{YE}(\mathrm{mg} / \mathrm{L})$ & $\mathrm{AC}(\mathrm{g} / \mathrm{L})$ & $\mathrm{AgNO}_{3}(\mathrm{mg} / \mathrm{L})$ & $F W(\mathrm{~g})$ & $D W(\mathrm{~g})$ & $G I$ \\
\hline 0.5 & $\mathbf{0 . 0}$ & $\mathbf{0 . 0}$ & $\mathbf{0 . 0}$ & $\mathbf{2 . 5 8 ^ { \mathrm { a } }}$ & $\mathbf{0 . 3 8}^{\mathrm{a}}$ & $\mathbf{5 . 1 6}$ \\
0.5 & 100 & - & - & $1.78^{\mathrm{b}}$ & $0.21^{\mathrm{b}}$ & 3.56 \\
0.5 & 200 & - & - & $1.46^{\mathrm{bc}}$ & $0.16^{\mathrm{bc}}$ & 2.92 \\
0.5 & 300 & - & - & $1.38^{\mathrm{bc}}$ & $0.15^{\mathrm{bc}}$ & 2.76 \\
0.5 & 400 & - & - & $1.23^{\mathrm{c}}$ & $0.13^{\mathrm{c}}$ & 2.46 \\
\hline 0.5 & - & 0.5 & - & $1.42^{\mathrm{b}}$ & $0.17^{\mathrm{b}}$ & 2.84 \\
0.5 & - & 1.0 & - & $1.15^{\mathrm{b}}$ & $0.13^{\mathrm{bc}}$ & 2.30 \\
0.5 & - & 1.5 & - & $1.12^{\mathrm{b}}$ & $0.11^{\mathrm{c}}$ & 2.24 \\
\hline 0.5 & - & - & 0.5 & $1.12^{\mathrm{b}}$ & $0.11^{\mathrm{c}}$ & 2.24 \\
\hline 0.5 & - & - & 1.0 & $1.5^{\mathrm{b}}$ & $0.17^{\mathrm{b}}$ & 3.0 \\
\hline 0.5 & - & - & 1.5 & $1.4^{\mathrm{b}}$ & $0.16^{\mathrm{b}}$ & 2.8 \\
\hline
\end{tabular}

\section{Discussion}

KIN is a PGR with the ability to enhance callus proliferation and regeneration by influencing mitosis, cytokinesis, total protein synthesis, lignin biosynthesis, vascular differentiation, and the differentiation of mature chloroplasts from protoplastids (Wan, 1988). However, it is indicated by the results in Table 1 that only a low quantity of KIN has these positive effects, which is in line 
with the work of Farzinebrahimi et al. (2014), who concluded that raising KIN concentration from $1 \mathrm{mg} / \mathrm{L}$ to $5 \mathrm{mg} / \mathrm{L}$ gradually lowers callus induction rate of Gardenia jasminoides Ellis. The same phenomenon was also observed in using BAP (6-benzylaminopurine, which is also a cytokinin) for callus induction of Pogostemon mollis Benth. (Lamiaceae) (Muthuraj, 2018). Specifically, only 0.5 $\mathrm{mg} / \mathrm{LBAP}$ could stimulate the highest callus amounts from stem and leaf explants of P. mollis. However, in several other species such as Nerium odorum, KIN completely suppresses callus formation with no callus produced by examined KIN concentrations (0.5-5 mg/L) (Prakasha, Umesha, 2018).

Several authors including Arivalagan et al. (2012), Wee (2015), and Rahman et al. (2019) demonstrated that combining high amounts of NAA with KIN had the effect of raising callus weight and induction rate. Particularly, Arivalagan et al. (2012) reported that MS media supplemented with combinations of NAA (1-2 mg/L) and KIN (0.5-1 $\mathrm{mg} / \mathrm{L}$ ) were among the most suitable culture media for Sauropus androgynus's callus growth. This result was agreed by Wee's research (2015) on $S$. androgynous. Specifically, $2 \mathrm{mg} / \mathrm{L}$ NAA and $1 \mathrm{mg} / \mathrm{L}$ KIN gave rise to the largest and heaviest calli from leaf explants, with an average $F W$ and expansion factor of $4.53 \mathrm{~g}$ and $18.50 \mathrm{~cm}^{2}$. In a study about Catharanthus roseus (L.) G. Don, Rahman et al. (2019) found the stimulatory effect of $2 \mathrm{mg} / \mathrm{L} \mathrm{KIN}$ $+1 \mathrm{mg} / \mathrm{L}$ NAA combination, which is enhancing the formation of calli having the greatest average $F W(1.477 \mathrm{~g})$. Being similar to these findings, the average $F W$ of $C$. orchioides calli treated with the optimal NAA + KIN combination in our research is significantly high $(3.8 \mathrm{~g})$. This result was different from that of Nagesh et al. (2010) claiming that $C$. orchioides calli grown on MS media given NAA and KIN only had the low average $F W$ of $0.713 \mathrm{~g}$. However, the quality of the produced $C$. orchioides calli was low, with the black color and low $D W$. Therefore, combining NAA and KIN seems to be inappropriate for C. orchioides's callus proliferation and we then only used $0.5 \mathrm{mg} / \mathrm{l} \mathrm{KIN}$ in further experiments. The found negative impact might be caused by ethylene, a growth inhibitor, which is synthesized when NAA presents in culture media (George, 2008).

As it is mentioned above, there are only two published studies on callus proliferation of C. orchioides (Dhenuka, 1999; Nagesh, 2010). However, those studies only focused on examining the impacts of PGRs on callus induction of this plant without considering other factors, which have been reported to be able to affect the formation of calli, such as photoperiod, mineral media, AC, and YE (Vasil, Hildebrandt, 1966; Pan, Staden, 1998; Ma, 2009; Wani, 2014). Thus, we examined those new factors to find out how $C$. orchioides calli responded.

As it is highlighted in Table 3, lowering nutrients in MS medium in half created the optimal medium for callus proliferation of $C$. orchioides. There are also researches on different species providing a similar conclusion about the strong growth of calli on $1 / 2$ MS medium. First of all, after testing MS, $1 / 2$ MS, and $1 / 4$ MS medium, Wani et al. (2014) reported that maximum callus growth of Costus pictus was obtained when $1 / 2$ MS and $1 / 4$ MS were utilized while no callus formation was detected on full strength MS medium. Additionally, MS medium is proven to be not effective as $1 / 2 \mathrm{MS}$ medium in inducing callus of Boerhaavia paniculata Rich (Souza, 2014). Finally, in a study on Dendrocalamus hamiltonii, an insignificant difference in terms of promoting callus formation between the two most efficient media, namely MS and $1 / 2$ MS, was illustrated by Zang et al. (2016).

Illuminating callus cultures for 16 hours per day is the best photoperiod for callus growth of some species such as Litchi chinensis Sonn. and Nicotiana tabacum L. In particular, a high of $16.67 \mathrm{~g}$ callus was produced when L. chinensis leaf explants were incubated under the light regime of 16 light hours (L) : 8 dark hours (D) (Ma, 2009). Additionally, the results of comparing $16 \mathrm{~L}: 8 \mathrm{D}$ and $0 \mathrm{~L}: 24 \mathrm{D}$ shown by Siddique and Islam (2015) demonstrated that the optimal amount of $N$. tabacum L. callus $(97.20 \%)$ was obtained under light conditions while dark conditions could only produce a low quantity of watery, glossy silver calli with few embryogenic features. However, in the case of C. orchioides, a completely distinct phenomenon was found. Specifically, calli cultured on the medium put in dark condition were heavier and grew more vigorously than the ones incubated under the light regime of $16 \mathrm{~L}: 8 \mathrm{D}$. This finding might be explained by the photodegradation of natural auxins in calli and synthesis of phenolic compounds, which could inhibit enzymes having key roles in cell proliferation (Yeoman, Davidson, 1971).

In addition to factors having positive effects, the present research also figured out inhibiting factors namely YE, $\mathrm{AC}$, and $\mathrm{AgNO}_{3}$. Firstly, though $\mathrm{Ag}^{2+}$ cation (derived from $\mathrm{AgNO}_{3}$ ) is proven to have the ability to interfere with negative impacts of ethylene by binding to its receptors on the cell membrane 
(Goren et al., 1984; Yang, Hoffman, 1984; Bleecker et al., 1998), low levels of $C$. orchioides's callus growth were observed on all media supplemented with $\mathrm{AgNO}_{3}$. Secondly, the high adsorption capacity of $\mathrm{AC}$ might be the main reason for its inhibitory effect. Specifically, the change of $\mathrm{pH}$ and the loss of auxins, cytokinins, and vitamins caused by AC could make calli grow ineffectively in culture medium (Pan, Staden, 1998). Finally, the inverse correlation between YE concentrations and callus growth in our study was also found by Vasil and Hildebrandt (1966). Particularly, when YE quantity increased from 125 to $5000 \mathrm{mg} / \mathrm{L}$, callus proliferation of carrot (Daucus carota), endive (Cichorium endivia) and lettuce (Lactuca sativa) explants fell to the minimum values of $1.320 \mathrm{~g}, 2.425 \mathrm{~g}$, and $0.478 \mathrm{~g}$ respectively.
However, there are also authors including George et al. (2008) who claimed that YE could be used to promote plant growth because of its high amino acid content.

\section{Conclusion}

From the results illustrated in Fig. 4, it could be concluded that the following conditions are optimal for callus proliferation of $C$. orchioides:

1. Half-strength MS medium supplemented with $0.5 \mathrm{mg} / \mathrm{L} \mathrm{KIN}+30 \mathrm{~g} / \mathrm{L}$ sucrose $+8 \mathrm{~g} / \mathrm{L}$ agar.

2. MS medium supplemented with $0.5 \mathrm{mg} / \mathrm{L}$ $\mathrm{KIN}+30 \mathrm{~g} / \mathrm{L}$ sucrose $+8 \mathrm{~g} / \mathrm{L}$ agar and put in dark conditions (0 L : $24 \mathrm{D})$.

\section{REFERENCES}

Agrahari A. K., Panda S. K., Meher A., Padhan A. R., Khaliquzzama M. 2010. Phytochemical Screening of Curculigo Orchioides Gaertn. Root tubers. Journal of Chemical and Pharmaceutical Research 2(2): 107-111.

Ahn C. H., Yoon W. M., Ahn I. O. 1996. Effects of auxin and sucrose on cell growth and production of phenolic compounds in cell suspension culture of Panax ginseng C. A. Meyer. Journal of the Korean Society for Horticultural Science 37: 340-344.

Arivalagan U., Alderson P. G., Nagarajan A. 2012. Effect of growth hormones on callus induction of Sauropus androgynous (Sweet shoot). Annals of Biological Research 3(10): 4668-4674.

Biswas M., Das S. S., Dey S. 2013. Establishment of a Stable Amaranthus tricolor Callus Line for Production of Food Colorant. Food Science and Biotechnology 22(S): 1-8. DOI: 10.1007/s10068-013-0041-9

Bleecker A. B., Estelle M. A., Somerville C., Kende H. 1998. Insensitivity to ethylene conferred by a dominant mutation in Arabidopsis thaliana. Science 241(4869): DOI: 10.1126/science.241.4869.1086

Bourgaud F., Gravot A., Milesi S., Gontier E. 2001. Production of plant secondary metabolites: a historical perspective. Plant Science 161: 839-851. DOI: 10.1016/S0168-9452(01)00490-3

Cao D. P., Zheng Y. N., Qin L. P., Han T., Zhang H., Rahman K., Zhang Q. Y. 2008. Curculigo orchioides, a traditional Chinese medicinal plant, prevents bone loss in ovariectomized rats. Maturitas 59(4): 373-380. DOI: 10.1016/j.maturitas.2008.03.010

Chauhan N. S., Dixit V. K. 2007. Antihyperglycemic activity of the ethanolic extract of Curculigo orchioides Gaertn. Pharmacognosy Magazine 3(12): 236-239.

Dhenuka S., Balakrishna P., Anand A. 1999. Indirect Organogenesis from the Leaf Explants of Medicinally Important Plant Curculigo orchioides Gaertn J. Plant Biochemistry \& Biotechnology 8: 113-115. DOI: 10.1007/ bf03263070

Duncan D. B. 1955. Multiple range and multiple F tests. Biometrics 11: 1-42. DOI: 10.2307/3001478

Farzinebrahimi R., Taha R. M., Rashid K., Yaacob J. S. 2014. The effect of various media and hormones via suspension culture on secondary metabolic activities of (Cape Jasmine) Gardenia jasminoides Ellis. The Scientific World Journal 2014: 1-7. DOI: 10.1155/2014/407284

Fett Neto A. G., Zhang W. Y., DiCosmo F. 1994. Kinetics of taxol production, growth and nutrient uptake in cell suspensions of Taxus cuspidata. Biotechnology and Bioengineering 44: 205-210. DOI: 10.1002/bit.260440209

George E. F., Hall M. A., Klerk G-J. D. 2008. The components of plant tissue culture media II: organic additions, osmotic and $\mathrm{pH}$ effects, and support systems. Plant Propagation by Tissue Culture (3rd edition) Springer: 115-173. DOI: $10.1007 / 978-1-4020-5005-3 \_4$

Goren L., Mattoo A. K., Anderson J. D. 1984. Ethylene binding during leaf development and senescence. Journal of Plant Physiology 117(3): 243-248. DOI: 10.1016/s0176-1617(84)80006-1

Jaiswal K., Batra K. A., Mehta B. K. 1984. The antimicrobial efficiency of root oil against human pathogenic bacteria and phytopathogenic fungi. Journal of Phytopathology 109(1): 90-93. DOI: 10.1111/j.1439-0434.1984. tb04234.x

Jin C. S., Keng C. L. 2013. Factors affecting the selection of callus cell lines and the preparation of the cell suspension culture of Artemisia annua L. Plant Tissue Culture and Biotechnology 23(2): 157-163. DOI: 10.3329/ ptcb.v23i2.17507 
Kubo M., Namba K., Nagatnoto N., Nagao T., Nakanishi J., Uuo H., Nishimura H. 1983. A new phenolic glycoside, curculigoside from rhizomes of Curculigo orchioides. Plant Medica 47(1): 52-55. DOI: 10.1055/s-2007969949

Lakshmi N., Kumari S., Sharma Y., Sharma N. 2004. New phytoconstituents from the rhizomes of Curculigo orchioides. Pharmaceutical Biology 42(2): 131-134. DOI: 10.1080/13880200490510964

Wee S. L. 2015. The effects of elicitors and precursor on in vitro cultures of sauropus androgynus for sustainable metabolite production and antioxidant capacity improvement. $\mathrm{PhD}$ thesis. University of Nottingham.

Ma X. Y., Yi G. J., Huang X. L., Zeng J. W. 2009. Leaf callus induction and uspension culture establishment in lychee (Litchi chinensis Sonn.) cv. Huaizhi. Acta Physiol Plant 31(2): 401-405. DOI: 10.1007/s11738-008-0223-x

Madhavan V., Joshi R., Murali A., Yoganarasimhan S. N. 2007. Antidiabetic activity of Curculigo orchioides root tuber. Pharmaceutical Biology 45(1): 18-21. DOI: 10.1080/13880200601026259

Miguel-Chavez R. S., Soto-Hernandez M., Ramos-Valdivia A. C., Kite G. 2007. Alkaloid production in elicited cell suspension cultures of Erythrina americana Miller. Phytochemistry Reviews 6: 167-173. DOI: 10.1007/s11101006-9045-x

Misra T. N., Singh R. S., Tripathi D. M. 1984. Aliphatic compounds from Curculigo orchioides rhizomes. Phytochemistry 23(10): 2369-2371. DOI: 10.1016/s0031-9422(00)80556-7

Misra T. N., Singh R. S., Tripathi D. M., Sharma S. C. 1990. Curculigol, a cycloartane triterpene alcohol from Curculigo orchioides. Phytochemistry 29(3): 929-931. DOI: 10.1016/0031-9422(90)80048-1

Miura H., Kitamura Y., Ikenaga T., Mizobe K., Shimizu T., Nakamura M., Kato Y., Yamada T., Maitani T., Goda Y. 1998. Anthocyanin production of Glehnia littoralis callus cultures. Phytochemistry 48(2): 279-283. DOI: 10.1016/ S0031-9422(97)01115-1

Murashige T., Skoog F. 1962. A revised medium for rapid growth and bio assays with tobacco tissue cultures. Physiologia plantarum 15(3): 473-497.

Muthuraj K., Kaffoor H. A., Nagarajan N. 2018. Establishment of in vitro protocol and impact of mycorrhization with phosphobacteria on micro propagated Pogostemon mollis Benth. (Lamiaceae). Journal of Taibah University for Science 12(1): 1-10. DOI: 10.1080/16583655.2018.1451060

Nagesh K. S., Shanthamma C. 2009. Antibacterial activity of Curculigo orchioides rhizome extract on pathogenic bacteria. African Journal of microbiology research 3(1): 5-9. DOI: 10.5897/AJMR.9000048

Nagesh K. S., Shanthamma C., Pullaiah T. 2010. Somatic embryogenesis and plant regeneration from callus cultures of Curculigo orchioides Gaertn. Indian Journal of Biotechnology 9(4): 408-413.

Pan M. J., Staden J. V. 1998. The use of charcoal in in vitro culture - A review. Plant Growth Regulation 26: 155-163. DOI: 10.1023/a:1006119015972

Pandit P., Singh A., Bafna A. R., Kadam P. V., Patil M. J. 2008. Evaluation of antiasthmatic activity of Curculigo orchioides Gaertn. rhizomes. Indian Journal Pharmaceutical Sciences 70(4): 440-444. DOI: 10.4103/0250474X.44590

Prakasha A., Umesha S. 2018. Effect of growth hormones in induction of callus, antioxidants, and antibacterial activity in Nerium odorum. Journal of Applied Biology \& Biotechnology 6(04): 21-25. DOI: 10.7324/JABB.2018.60404

Rahman N. N. A., Rosli R., Kadzimin S., Hakiman M. 2019. Effects of auxin and cytokinin on callus induction in Catharanthus roseus (L.) G. Don. Fundamental and Applied Agriculture 4(3): 928-932. DOI: 10.5455/faa.54779

Siddique A. B., Islam S. S. 2015. Effect of light and dark on callus induction and regeneration in Tobacco (Nicotiana tabacum L.). Bangladesh Journal of Botany 44(4): 643-651.

Singh V. 2009. Ethnobotany and Medicinal Plants of India and Nepal. Vol. 3. Scientific Publishers. 338 pp.

Souza J. M. M., Berkov S., Santos A. S. 2014. Improvement of friable callus production of Boerhaavia paniculata Rich and the investigation of its lipid profile by GC/MS. Anais da Academia Brasileira de Ciências 86(3): $1015-1027$. DOI: 10.1590/0001-3765201420130098

Vasil I. K., Hildebrandt A. C. 1966. Growth and chlorophyll production in plant callus tissues grown in vitro. Planta 68(1): 69-82. DOI: 10.1007/bf00385372

Venukumar M. R., Latha M. S. 2002. Antioxidant activity of Curculigo orchioides in carbon tetrachloride induced hepatopathy in rats. Indian Journal of Clinical Biochemistry 17(2): 80-87. DOI: 10.1007/bf02867976

Wala B. B., Jasrai Y. T. 2003. Micropropagation of an eendangered medicinal plant: Curculigo orchioides Gaertn. Plant Tissue Culture 13(1): 13-19.

Wan Y., Sorensen E. L., Liang G. H. 1988. The effects of kinetin on callus characters in alfalfa (Medicago sativa L.). Euphytica 39(3): 249-254. DOI: 10.1007/bf00037103

Wani S. J., Kagdi I. A., Tamboli P. S., Nirmalkar V. S., Patil S. N., Sidhu A. K. 2014. Optimization of MS media for callus and suspension culture of Costus pictus. International Journal of Scientific \& Engineering Research 5(2): 390-394.

Xи J. P., Xи R. S. 1992. Cycloartane-type sapogenins and their glycosides from Curculigo orchioides. Phytochemistry 31(7): 2455-2458. DOI: 10.1016/0031-9422(92)83298-d 
Yang S. F., Hoffman N. E. 1984. Ethylene biosynthesis and its regulation in higher plants. Annual Review of Plant Physiology 35(1): 155-189. DOI: 10.1146/annurev.pp.35.060184.001103

Yeoman M. M., Davidson A. W. 1971. Effect of light on cell division in developing callus cultures. Annals of Botany 35(5): 1085-1100. DOI: 10.1093/oxfordjournals.aob.a084544

Zang Q., Zhou L., Zhuge F., Yang H., Wang X., Lin X. 2016. Callus induction and regeneration via shoot tips of Dendrocalamus hamiltonii. SpringerPlus 5(1): 1799. DOI: 10.1186/s40064-016-3520-7

Zuo A. X., Shen Y., Jianga Z. Y., Zhanga X. M., Zhoua J., Lu J., Chen J. J. 2010. Three New Dimeric Orcinol Glucosides from Curculigo orchioides. Helvetica Chimica Acta 93(3): 504-510. DOI:10.1002/hlca.200900240 